\title{
Na-K-Cl Cotransporter Contributes to Glutamate-Mediated Excitotoxicity
}

\author{
Joe Beck, ${ }^{1,3}$ Brett Lenart, ${ }^{1}$ Douglas B. Kintner, ${ }^{1}$ and Dandan Sun ${ }^{1,2}$ \\ Departments of ${ }^{1}$ Neurological Surgery, ${ }^{2}$ Physiology, and ${ }^{3}$ Pathology, University of Wisconsin Medical School, Madison, Wisconsin 53792
}

\begin{abstract}
We hypothesized that cation-dependent $\mathrm{Cl}^{-}$transport protein Na-K-Cl cotransporter isoform 1 (NKCC1) plays a role in the disruption of ion homeostasis in cerebral ischemia. In the current study, a role for $\mathrm{NKCC1}$ in neuronal death was elucidated in neurotoxicity induced by glutamate and oxygen and glucose deprivation (OGD). Incubation of cortical neurons cultured for $14-15 \mathrm{~d}$ in vitro (DIV) with $100 \mu \mathrm{M}$ glutamate for $24 \mathrm{hr}$ resulted in $50 \%$ cell death. Three hours of OGD followed by $21 \mathrm{hr}$ of reoxygenation led to $70 \%$ cell death. Inhibition of NMDA receptors with dizocilpine hydrogen maleate $(1 \mu \mathrm{M})$ prevented both OGD- and glutamate-mediated cell death. Moreover, blocking of NKCC1 activity with bumetanide $(5-10 \mu \mathrm{M})$ abolished glutamate- or OGD-induced neurotoxicity. Bumetanide was ineffective if added after 10-120 min of glutamate incubation or 3-6 hr of OGD treatment. Accumulation of intracellular $\mathrm{Na}^{+}$and ${ }^{36} \mathrm{Cl}$ content after NMDA receptor activation was inhibited by bumetanide. Blockage of NKCC1 significantly attenuated cell swelling after OGD or NMDA receptor activation. This neuroprotection was age dependent. Inhibition of NKCC1 did not protect DIV 7-8 neurons against OGD-mediated cell death. In contrast, cell death in DIV 7-8 neurons was prevented by the protein-synthesis inhibitor, cycloheximide. Taken together, the results suggest that NKCC1 activity is involved in the acute excitotoxicity as a result of excessive $\mathrm{Na}^{+}$and $\mathrm{Cl}^{-}$entry and disruption of ion homeostasis.
\end{abstract}

Key words: excitotoxicity; active $\mathrm{Cl}^{-}$transport; $\mathrm{Na}^{+}$entry; cell volume; necrosis; bumetanide

\section{Introduction}

$\mathrm{Cl}^{-}$movement has been shown to be a central component of the acute excitotoxic response in neurons (Rothman, 1985; Olney et al., 1986; Nicklas et al., 1987). The acute excitotoxicity is thought to be mediated by excessive depolarization of the postsynaptic membrane. This results in an osmotic imbalance when countered by an influx of $\mathrm{Cl}^{-}, \mathrm{Na}^{+}$, and water, leading to eventual lysis. Removal or reduction of $\mathrm{Cl}^{-}$from extracellular medium during excitatory amino acid exposure completely eliminates the acute excitotoxic response in hippocampal (Rothman, 1985) and retinal (Olney et al., 1986; Nicklas et al., 1987) neurons. A significant increase in intracellular $\mathrm{Cl}^{-}$concentration $\left(\left[\mathrm{Cl}^{-}\right]_{\mathrm{i}}\right)$ is observed in hippocampal neurons during OGD (Inglefield and SchwartzBloom, 1998). Although the mechanisms underlying the $\mathrm{Cl}^{-}$dependent excitotoxicity are not yet understood, blockage of $\mathrm{Cl}^{-}$ entry through the $\mathrm{Cl}^{-} / \mathrm{HCO}_{3}{ }^{-}$exchanger or GABA receptor effectively protects cells against the acute excitotoxicity (Zeevalk et al., 1989; Chen et al., 1998; Inglefield and Schwartz-Bloom, 1998).

We hypothesized that $\mathrm{Na}-\mathrm{K}-\mathrm{Cl}$ cotransporter isoform 1 (NKCC1) may also contribute to the $\mathrm{Cl}^{-}$movement during excitotoxicity. The electroneutral NKCC1 transports $\mathrm{Na}^{+}, \mathrm{K}^{+}$, and $\mathrm{Cl}^{-}$into cells under physiological conditions (Russell, 2000). NKCC1 is characteristically inhibited by the sulfamoylbenzoic acid "loop" diuretics, such as bumetanide and furosemide (Russell, 2000). NKCC1 is important in the maintenance of intracel-

\footnotetext{
Received Dec. 17, 2002; revised April 4, 2003; accepted April 7, 2003.

This work was supported in part by National Institutes of Health Grant R01NS38118 and National Science Foundation Career Award IBN9981826 to D.S.

Correspondence should be addressed to Dr. Dandan Sun, Department of Neurological Surgery, Medical School, University of Wisconsin, H4/332, Clinical Sciences Center, 600 Highland Avenue, Madison, WI 53792. E-mail: sun@neurosurg.wisc.edu.

Copyright $\odot 2003$ Society for Neuroscience $\quad$ 0270-6474/03/235061-08\$15.00/0
}

lular $\mathrm{Cl}^{-}$in neurons and contributes to GABA-mediated depolarization in immature neurons (Misgeld et al., 1986; Sun and Murali, 1998; Sung et al., 2000; Alvarez-Leefmans, 2001). Thus, NKCC1 may affect neuronal excitability through regulation of $\left[\mathrm{Cl}^{-}\right]_{\mathrm{i}}$ (Sung et al., 2000; Jang et al., 2001). In addition, activation of the ionotropic glutamate NMDA receptor, the AMPA receptor, and the metabotropic glutamate receptor (group I) significantly stimulates NKCC1 activity in cortical neurons (Schomberg et al., 2001).

Our recent study reveals an upregulation of NKCC1 protein expression in the cortex at $24 \mathrm{hr}$ reperfusion after focal ischemia (Yan et al., 2001). Pharmacological inhibition of NKCC1 with bumetanide results in a significant reduction of infarction volume (Yan et al., 2001). In addition, water content increase is $70 \%$ less in the bumetanide-treated brains (Yan et al., 2001). These results strongly suggest that NKCC1 is important in ischemic neuronal damage. However, the cellular mechanisms by which NKCC1 contributes to ischemic cell death have not been defined. In this study, we report that inhibition of NKCC1 activity abolished glutamate-mediated neurotoxicity and significantly attenuated OGD-induced neuronal death. Thus, NKCC1 may be involved in ischemic cell death through an association with excitotoxicity.

A preliminary report was presented at the Ninth International Symposium on Pharmacology of Cerebral Ischemia (Beck et al., 2002).

\section{Materials and Methods}

Cortical neuron and astrocyte cultures. Primary rat neurons were cultured using techniques established in our laboratory as described previously (Schomberg et al., 2001). Embryonic day (E) 17 pregnant rats were anesthetized with halothane and killed. Fetuses were removed and rinsed in cold HBSS. The cortices were removed, minced, and rinsed in HBSS. The tissues were treated with $0.2 \mathrm{mg} / \mathrm{ml}$ trypsin at $37^{\circ} \mathrm{C}$ for $25 \mathrm{~min}$. The cells were centrifuged briefly, and the pellet was washed and triturated thor- 
oughly in HBSS. Cell suspension was filtered through a $70 \mu \mathrm{m}$ cell strainer. The cell suspension was diluted in Eagle's minimal essential media (EMEM) containing $100 \mathrm{U} / \mathrm{ml}$ penicillin and $100 \mu \mathrm{g} / \mathrm{ml}$ streptomycin, 10 mm glutamine, $10 \%$ fetal bovine serum, and $10 \%$ horse serum. Live cells $\left(6.25 \times 10^{5}\right)$ were added to each well of a poly-D-lysine-coated 24-well plate and incubated at $37^{\circ} \mathrm{C}$ in an incubator (model 3110, Thermo Forma, Marietta, $\mathrm{OH}$ ) with $5 \% \mathrm{CO}_{2}$ and atmospheric air. After $96 \mathrm{hr}$ in culture, cultures were refed with EMEM containing $4 \mu \mathrm{M}$ cytosine arabinofuranoside (Ara-c) for $72 \mathrm{hr}$. Ara-c is a mitotic inhibitor that prevents growth of glial cells. After the Ara-c treatment, cultures were refed with EMEM containing both $10 \%$ fetal bovine and 10\% horse sera.

Astrocytes were prepared from the same cortical cell suspension as described above with the following changes. The cell suspension was diluted in EMEM containing $100 \mathrm{U} / \mathrm{ml}$ penicillin and $100 \mu \mathrm{g} / \mathrm{ml}$ streptomycin, $10 \mathrm{~mm}$ glutamine, and $10 \%$ fetal bovine serum; $1.2 \times 10^{4}$ live cells per well were seeded in collagen-coated 24-well plates.

OGD treatment. DIV 7-8 and DIV 14-15 neuronal cultures were grown in 24-well plates. The cells were rinsed twice with an isotonic OGD solution, $\mathrm{pH} 7.4$, containing (in mM): 0 glucose, $20 \mathrm{NaHCO}_{3}, 120 \mathrm{NaCl}$, $5.36 \mathrm{KCl}, 0.33 \mathrm{Na}_{2} \mathrm{HPO}_{4}, 0.44 \mathrm{KH}_{2} \mathrm{PO} 4,1.27 \mathrm{CaCl}_{2}, 0.81 \mathrm{MgSO}_{4}$. Cells were incubated in $0.5 \mathrm{ml}$ of the OGD solution in a hypoxic incubator (model 3130, Thermo Forma) containing $94 \% \mathrm{~N}_{2}, 1 \% \mathrm{O}_{2}$, and $5 \% \mathrm{CO}_{2}$. The oxygen level in the medium of cultured cells in 24 -well plates was monitored with an oxygen probe (model M1-730, Microelectrodes, Bedford, $\mathrm{NH}$ ) and decreased to $\sim 2-3 \%$ after $60 \mathrm{~min}$ in the hypoxic incubator. The OGD incubation was $3 \mathrm{hr}$ for DIV $14-15$ neurons or $8 \mathrm{hr}$ for DIV 7-8 neurons. For reoxygenation, the cells were incubated for $24 \mathrm{hr}$ in 0.5 $\mathrm{ml}$ of EMEM containing $5.5 \mathrm{~mm}$ glucose at $37^{\circ} \mathrm{C}$ in the incubator with $5 \%$ $\mathrm{CO}_{2}$ and atmospheric air. Normoxic control cells were incubated in 5\% $\mathrm{CO}_{2}$ and atmospheric air in a buffer identical to the OGD solution except for the addition of $5.5 \mathrm{~mm}$ glucose. In the drug treatment studies, cells were pretreated with $10 \mu \mathrm{M}$ bumetanide or $1 \mu \mathrm{M}$ dizocilpine hydrogen maleate (MK801) for 30 min before the OGD treatment. Bumetanide or MK801 was present in all subsequent washes and incubations. For postischemic treatment, bumetanide $(10 \mu \mathrm{M})$ was added 3, 4, and $6 \mathrm{hr}$ after induction of OGD treatment.

Glutamate treatment. DIV 14-15 neuron cultures were incubated in EMEM containing $100 \mu \mathrm{M}$ glutamate at $5 \% \mathrm{CO}_{2}$ and atmospheric air for $24 \mathrm{hr}$ at $37^{\circ} \mathrm{C}$. For the drug pretreatment study, 0.5, 1.0, 5.0, or $10 \mu \mathrm{M}$ bumetanide or $1 \mu \mathrm{M}$ MK801 was added in cultures $30 \mathrm{~min}$ before the addition of glutamate, and cells were subsequently incubated for $24 \mathrm{hr}$ at $37^{\circ} \mathrm{C}$. For the time course studies, bumetanide was added either concurrently with glutamate or 10-120 min after the glutamate treatment, as indicated.

Measurement of cell death. Cell viability was assessed by propidium iodide (PI) uptake and retention of calcein using a Nikon TE 300 inverted epifluorescence microscope. Cultured neurons were rinsed with the isotonic control buffer and incubated with $1 \mu \mathrm{g} / \mathrm{ml}$ calcein-AM and 10 $\mu \mathrm{g} / \mathrm{ml} \mathrm{PI}$ in the same buffer at $37^{\circ} \mathrm{C}$ for $35 \mathrm{~min}$. For cell counting, cells were rinsed with buffer and visualized using a Nikon $20 \times$ objective lens. Calcein fluorescence was visualized using FITC filters [excitation (Ex) $488 \mathrm{~nm}$; emission (Em) $515 \mathrm{~nm}$ ], and PI fluorescence was visualized using Texas Red filters (Ex 536 nm; Em 645 nm). Images were collected using a Princeton Instruments MicroMax CCD camera. In a blind manner, a total of 1000 cells per condition were counted using MetaMorph image-processing software (Universal Imaging, Downingtown, PA). Cell mortality was expressed as the ratio of PI-positive cells to the sum of calcein-positive and PI-positive cells.

Intracellular $\mathrm{Cl}^{-}$content measurement. Cells on 24-well plates were preincubated at $37^{\circ} \mathrm{C}$ for $30 \mathrm{~min}$ in HEPES-MEM ${ }^{36} \mathrm{Cl}(0.4 \mu \mathrm{Ci} / \mathrm{ml})$, as described previously (Schomberg et al., 2003). In our previous study, steady-state intracellular ${ }^{36} \mathrm{Cl}$ was reached by $10 \mathrm{~min}$ incubation and maintained through $60 \mathrm{~min}$ (Schomberg et al., 2003). Thus, a $30 \mathrm{~min}$ preincubation with ${ }^{36} \mathrm{Cl}$ was used in the current study. The cells were then incubated in HEPES-MEM (Schomberg et al., 2001) containing ${ }^{36} \mathrm{Cl}(0.4 \mu \mathrm{Ci} / \mathrm{ml})$ in either the presence or absence of $10 \mu \mathrm{M}$ bumetanide, $1.0 \mu \mathrm{M}$ MK801, and $100 \mu \mathrm{M}$ NMDA for $15 \mathrm{~min}$. Thus, the specific activity of ${ }^{36} \mathrm{Cl}$ in HEPES-MEM was constant under all conditions. Intracellular ${ }^{36} \mathrm{Cl}$ content measurement was terminated by three washes with $1 \mathrm{ml}$ ice-cold washing buffer containing (in $\mathrm{mm}$ ): $118 \mathrm{NaCl}, 26 \mathrm{NaHCO}_{3}, 1.8$ $\mathrm{CaCl}_{2}, \mathrm{pH} 7.40$. Radioactivity of the cellular extract in $1 \%$ SDS was analyzed by liquid scintillation counting (Packard 1900CA, Downers Grove, IL). In each experiment, specific activities (counts per micromole per minute) of ${ }^{36} \mathrm{Cl}$ were determined for each assay condition and used to calculate intracellular $\mathrm{Cl}^{-}$content (micromole per milligram per protein). Protein content was measured in each sample using the bicinchoninic acid method (Schomberg et al., 2003).

Intracellular $\mathrm{Na}^{+}$measurement. Intracellular $\mathrm{Na}^{+}$concentration $\left(\left[\mathrm{Na}^{+}\right]_{\mathrm{i})}\right.$ was measured with the fluorescent dye sodium binding benzofuran isophthalate (SBFI-AM) as described previously (Su et al., 2002a). Cultured neurons grown on coverslips were loaded with $2.5 \mu \mathrm{M}$ SBFI-AM at room temperature in HEPES-MEM containing $0.05 \%$ pluronic acid for $45 \mathrm{~min}$. The coverslips were placed in an open-bath imaging chamber (Model RC24, Warner Instruments, Hamden, CT) containing HEPES-MEM at ambient temperature. To reduce phototoxicity, the HEPES-MEM in these experiments was supplemented with (in mM): 1.0 pyruvate, 0.4 ascorbic acid, 0.01 troloxC, and 0.1 butylated hydroxyanisole (Dent et al., 1999). Using a Nikon TE 300 inverted epifluorescence microscope and a $40 \times$ Super Fluor oil immersion objective lens, neurons were excited every $30 \mathrm{sec}$ at 345 and $385 \mathrm{~nm}$, and the emission fluorescence at $510 \mathrm{~nm}$ was recorded. Images were collected and analyzed with the MetaFluor image-processing software (Universal Imaging Corporation) as described previously (Su et al., 2002a). The ratios of 340/380 were recorded for $10 \mathrm{~min}$ in HEPES-MEM, HEPES-MEM plus $1 \mu \mathrm{M}$ MK801, or HEPES-MEM plus $5 \mu \mathrm{M}$ bumetanide to establish baselines, and then the bath chamber buffer was changed to HEPES-MEM with $60 \mu \mathrm{M}$ NMDA, $60 \mu \mathrm{M}$ NMDA plus $1 \mathrm{MK} 801$, or $60 \mu \mathrm{M}$ NMDA plus $5 \mu \mathrm{M}$ bumetanide for $20 \mathrm{~min}$. In the bumetanide experiments, cells were preincubated in $5 \mu \mathrm{M}$ bumetanide for $10 \mathrm{~min}$ to ensure completed inhibition of the NKCC1. At the end of each experiment, absolute $\left[\mathrm{Na}^{+}\right]_{i}$ was determined for each cell by calibrating the SBFI fluorescence ratio with solutions containing $0,10,20,40$, or $80 \mathrm{~mm}\left[\mathrm{Na}^{+}\right]_{\mathrm{o}}$ plus monensin $(10$ $\mu \mathrm{M})$ and gramicidin $(3 \mu \mathrm{M})$ to equilibrate extracellular and intracellular $\left[\mathrm{Na}^{+}\right]$, as described previously (Su et al., 2002a).

In our preliminary study, we observed severe phototoxicity and excitotoxicity in neurons under $37^{\circ} \mathrm{C}$ conditions. Cells failed to exhibit concentration-dependent changes in the SBFI fluorescence ratios during calibration after NMDA treatment at $37^{\circ} \mathrm{C}$. Thus, in the current study, intracellular $\mathrm{Na}^{+}$measurements were performed at room temperature.

Measurement of cell swelling. Concurrent with the $\left[\mathrm{Na}^{+}\right]_{\mathrm{i}}$ measurement after NMDA exposure, relative cell volume changes were monitored using video-enhanced differential interference contrast (DIC) microscopy, as described in our previous study (Su et al., 2002a). Cells were visualized every $1.5 \mathrm{~min}$ using a Nikon $40 \times$ Plan Fluor DIC objective lens, and the images were recorded. The mean cross-sectional area (CSA) was calculated after tracing the perimeter of the cell body with MetaMorph image-processing software.

For cell-swelling measurement after OGD, a region of neurons on a plate (DIV 14-15) was marked with a marking pen, and images were recorded as described above. This culture then underwent $3 \mathrm{hr}$ of OGD treatment. After $3 \mathrm{hr}$ of the incubation, neurons in the same marked regions were visualized, and images of the same group of cells were recorded. The control CSA values were obtained with a $20 \times$ plan objective before the $3 \mathrm{hr}$ incubation treatment. Sister cultures were treated with the isotonic normoxic buffer in $5 \% \mathrm{CO}_{2}$ and atmospheric air for $3 \mathrm{hr}$. In the bumetanide studies, bumetanide $(10 \mu \mathrm{M})$ was added to cultures immediately before the OGD treatment, and cultures were treated with OGD for $3 \mathrm{hr}$. Relative changes of mean CSA (CSAr) values were obtained in cells at the end of $3 \mathrm{hr}$ exposure to normoxic, OGD, or OGD plus bumetanide. CSAr values were calculated as experimental values/control values.

Materials. Bumetanide, glutamic acid, NMDA, NMDA receptor antagonist MK801, cytosine-1- $\beta$-D arabinofuranoside, pyruvate, l-ascorbic acid, troloxC, butylated hydroxyanisole, propidium iodide, and cycloheximide were purchased from Sigma (St. Louis, MO). Calcein-AM was from Dojindo Molecular Technologies (Gaithersburg, MD). SBFI was from Molecular Probes (Eugene, OR). EMEM and HBSS were from Mediatech Cellgro (Herndon, VA). Fetal bovine and horse 

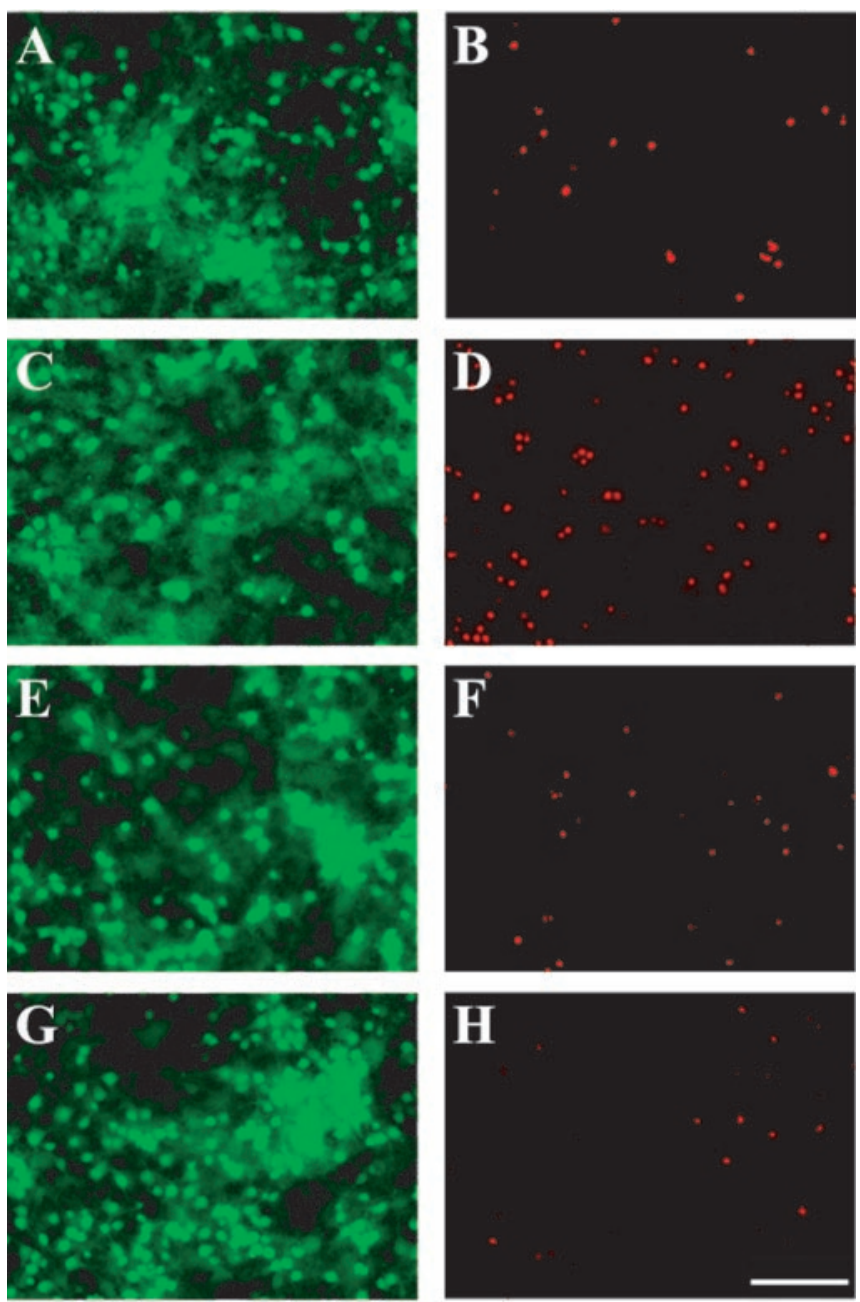

Figure 1. Inhibition of NKCC1 reduces cell mortality after glutamate-mediated neurotoxicity. $A-H$, Cell mortality was assessed in DIV $14-15$ neurons by $\mathrm{PI}$ and calcein-AM staining after $24 \mathrm{hr}$ of glutamate $(100 \mu \mathrm{M})$ treatment. Neurons were preincubated in EMEM in the presence or absence of $10 \mu \mathrm{m}$ bumetanide or $1 \mu \mathrm{m}$ MK801 for $30 \mathrm{~min}$ at $37^{\circ} \mathrm{C}$. Cells were then incubated with $100 \mu \mathrm{m}$ glutamate, glutamate plus bumetanide, glutamate plus MK801, or glutamate plus MK801 and bumetanide for $24 \mathrm{hr}$. Cells were stained with PI and calcein-AM for $30 \mathrm{~min}$ at $37^{\circ} \mathrm{C}$. Positively stained cells were visualized, and cell images were acquired. $A, C, E, G$, Calcein-AM. $B$, $D, F, H, P I . A, B$, Control. C, D, Glutamate. $E, F$, Glutamate plus bumetanide. $G, H$, Glutamate plus MK801. Scale bar, $256 \mu \mathrm{m}$.

sera were obtained from Hyclone Laboratories (Logan, UT). Chloride-36 was purchased from Amersham Biosciences (Piscataway, NJ).

\section{Results}

Pharmacological inhibition of NKCC1 reduces neuronal death after glutamate and OGD treatment

We hypothesized that stimulation of NKCC1 activity may lead to disruption of ion homeostasis and contribute to neuronal death. In this study, we first examined whether inhibition of NKCC1 is neuroprotective in excitotoxicity. A low level of cell death occurred in control conditions (Fig. 1A,B). Glutamate treatment $(100 \mu \mathrm{M})$ for $24 \mathrm{hr}$ led to $\sim 50 \%$ cell death in rat cortical neurons (DIV 14-15), as shown in Figure 1, $C$ and $D$. In the presence of glutamate $(100 \mu \mathrm{M})$ and bumetanide $(10 \mu \mathrm{M})$, the glutamatemediated cell damage was abolished (Fig. $1 E, F$ ). NMDA receptor antagonist MK801 (1 $\mu \mathrm{M})$ blocked the glutamate-mediated cell death (Fig. $1 G, H$ ). Figure $2 A$ illustrates the quantitative analysis of this study. Glutamate-mediated cell death was abolished by either bumetanide or MK801. NMDA (100 $\mu \mathrm{M})$ led to $60 \%$ cell death that was inhibited by bumetanide. Blocking of both NKCC1 and NMDA receptors did not further improve cell survival. Neither bumetanide nor MK801 affected the basal levels of cell death (Fig. $2 A$ ).

Bumetanide is a potent inhibitor for $\mathrm{NKCC} 1$ and has an $\mathrm{IC}_{50}$ of $0.2 \mu \mathrm{M}$ (O'Grady et al., 1987; Russell, 2000); however, bumetanide at high concentrations $(2 \mathrm{mM})$ has been reported to inhibit NMDA receptor activity (Lerma and Martin del Rio, 1992). To further establish that the bumetanide-mediated protection observed above is via inhibition of NKCC1 activity, we conducted a dose-dependent study of bumetanide at $0.5,1.0,5.0$, and $10 \mu \mathrm{M}$. As shown in Figure $2 B, 0.5$ and $1.0 \mu \mathrm{m}$ bumetanide significantly reduced glutamate-mediated cell death. A nearly complete protective effect of bumetanide was found at 5.0 and $10 \mu \mathrm{M}$. Either 5 or $10 \mu \mathrm{M}$ bumetanide was used in the rest of the study.

\section{Activity of NKCC1 is associated with the initial cell death} events of glutamate-mediated neurotoxicity

We hypothesized that activation of NKCC1 contributes to glutamate-mediated neurotoxicity by intracellular $\mathrm{Na}^{+}$and $\mathrm{Cl}^{-}$ overload during the initial stage of excitotoxicity. To test this possibility, we examined whether inhibition of NKCC1 is neuroprotective after glutamate receptors have been activated. As shown in Figure 3, blocking of NKCC1 either before glutamate treatment or concurrently with the addition of glutamate significantly reduced glutamate-mediated cell death $(p<0.05)$. In contrast, inhibition of NKCC1 at 10,30,60, or 120 min of glutamate treatment had no effect on neuronal death (Fig. 3) ( $p>$ 0.05 ). These results suggest that NKCC1 plays an important role during the initial stage of the glutamate-mediated neurotoxicity.

\section{NKCC1 is involved in OGD-mediated cell death}

Previous findings suggest that OGD-mediated cell death is essentially a result of NMDA ionotropic receptor-triggered excitotoxicity (Gwag et al., 1997). Rat cortical neuron cultures (DIV 1415) exhibited $70 \%$ cell death after $3 \mathrm{hr}$ of OGD and $21 \mathrm{hr}$ of reoxygenation compared with the cells in control conditions (Fig. $4 A)$. However, OGD-mediated cell death was significantly attenuated by $10 \mu \mathrm{m}$ bumetanide (Fig. $4 A)(p<0.05)$, consistent with the results of the glutamate study described above. Inhibition of the NMDA receptor with the antagonist MK801 $(1 \mu \mathrm{M})$ abolished OGD-induced cell death $(p<0.05)$. Moreover, no additional neuroprotection was found when both NMDA receptors and NKCC1 were blocked (Fig. 4A) ( $p>0.05)$. Furthermore, inhibition of protein synthesis by cycloheximide had no effects on OGD-induced cell death $(p>0.05)$, suggesting that apoptosis is not a prominent mechanism in this model. As shown in Figure $4 B$, inhibition of NKCC1 before or concurrently with the induction of OGD significantly reduced OGD-mediated neuronal death. However, neuroprotection was absent if bumetanide was added 3, 4, or $6 \mathrm{hr}$ after OGD treatment. This finding is consistent with the glutamate-mediated toxicity as described above.

Because $10 \mu \mathrm{M}$ bumetanide inhibits $\mathrm{GABA}_{\mathrm{A}}$ receptors (Sung et al., 2000), we investigated whether bumetanide-mediated protection is via inhibition of $\mathrm{GABA}_{\mathrm{A}}$ receptors, instead of NKCC1. We compared the effects of the $\mathrm{GABA}_{\mathrm{A}}$ receptor antagonist bicuculline and bumetanide on OGD-mediated cell death. As shown in Figure $4 C$, although bicuculline attenuated OGD-mediated cell death, protection was significantly lower than the one mediated by bumetanide. No additive effect was observed in the presence of both bicuculline and bumetanide. This implies that bumetanide mediates its effect via blocking of NKCC1. 
Neither a short treatment of OGD nor glutamate induces cell death in astrocytes

The cortical neuron culture preparation in the current study contained $20-30 \%$ astrocytes. To rule out a possible error in determination of cell mortality of neurons by counting contaminating astrocytes, we investigated whether astrocytes die after OGD or glutamate treatment. Compared with a control group of cultured astrocytes (Fig. 5A,B), treatment of cells (DIV 14$15)$ with either glutamate $(100 \mu \mathrm{M})$ for 24 hr (Fig. 5C,D) or OGD for 6 hr (Fig. $5 E, F$ ) failed to induce cell death. In addition, neither 8 hr OGD in DIV 7-8 astrocytes nor 3 hr OGD in DIV 14-15 astrocytes caused significant cell death $(2.1 \pm 1.1$ and $1.3 \pm$ $0.4 \%$, respectively). Therefore, the cells observed in the cultures throughout the study that were positively stained with PI were neurons.

\section{NKCC1 is not involved in OGD or glutamate-mediated cell death in immature neurons}

Immature neurons are less susceptible to glutamate-mediated neurotoxicity because of a low level of glutamate receptors (McDonald et al., 1997). However, functional NKCC1 protein is expressed in DIV 7-8 neurons (Sun and Murali, 1998). Thus, if the role of NKCC1 in cell death is associated with NMDA glutamate receptor-mediated excitotoxicity, inhibition of NKCC1 would not provide significant neuroprotection in immature neurons. As shown in Figure 6, $8 \mathrm{hr}$ of OGD and $16 \mathrm{hr}$ of reoxygenation led to $60 \%$ cell death in DIV $7-8$ neurons $(p<$ $0.05)$. Inhibition of NKCC1 with bumetanide $(10 \mu \mathrm{M})$ had no significantly protective effects on cell death in DIV 7-8 neurons. In contrast, cycloheximide $(1 \mu \mathrm{M})$ significantly attenuated OGDinduced cell death in DIV 7-8 neurons (Fig. 6). Moreover, glutamate did not induce cell death in DIV 7-8 neurons (Fig. 6, inset). There were no significant neuroprotective effects of either MK801 $(1 \mu \mathrm{M})$ or bumetanide $(10 \mu \mathrm{M})$ on cells at DIV 7-8 (Fig. 6 , inset). These data further suggest that NKCC1 is specifically involved in glutamate-mediated excitotoxicity.

\section{NKCC1 contributes to intracellular $\mathrm{Na}^{+}$and $\mathrm{Cl}^{-}$} accumulations and cell swelling during excitotoxicity Changes of $\left[\mathrm{Na}^{+}\right]_{\mathrm{i}}$ and intracellular $\mathrm{Cl}^{-}$content were monitored during activation of NMDA receptors. The mean resting $\left[\mathrm{Na}^{+}\right]_{\mathrm{i}}$ level was $7.4 \pm 1.8 \mathrm{~mm}$ in cortical neurons (Fig. $7 A, B$ ). On exposure to $60 \mu \mathrm{M}$ NMDA and activation of NMDA receptors, $\left[\mathrm{Na}^{+}\right]_{\mathrm{i}}$ increased abruptly by nearly $10 \mathrm{~mm}$ at the first minute $\left(\left[\mathrm{Na}^{+}\right]_{\mathrm{i}}\right.$ of $17.3 \pm 3.7 \mathrm{mM}) .\left[\mathrm{Na}^{+}\right]_{\mathrm{i}}$ increased further and reached $39.5 \pm 9.5$ $\mathrm{mM}$ after 20 min exposure to NMDA. These increases in $\left[\mathrm{Na}^{+}\right]_{\mathrm{i}}$ can be blocked by MK801. In the presence of $1 \mu \mathrm{M} \mathrm{MK801,} 60 \mu \mathrm{M}$ NMDA did not trigger a significant rise of $\left[\mathrm{Na}^{+}\right]_{\mathrm{i}}(6.8 \pm 1.1 \mathrm{mM}$ at $1 \mathrm{~min}$ and $7.1 \pm 1.6 \mathrm{~mm}$ at $20 \mathrm{~min}$ ). Interestingly, inhibition of NKCC1 activity with bumetanide had no significant effect on the initial rise of intracellular $\mathrm{Na}^{+}$accumulation $(13.0 \pm 1.7 \mathrm{mM}$ at $1 \mathrm{~min}$ ); however, bumetanide significantly attenuated the rise of $\left[\mathrm{Na}^{+}\right]_{\mathrm{i}}$ by $52 \%$ after $20 \mathrm{~min}$ of exposure of NMDA $\left(\left[\mathrm{Na}^{+}\right]_{\mathrm{i}}\right.$ of $15.6 \pm 2.3 \mathrm{~mm})$. This study further suggests that activation of NKCC1 activity contributes to NMDA-mediated rise in $\left[\mathrm{Na}^{+}\right]_{\mathrm{i}}$.

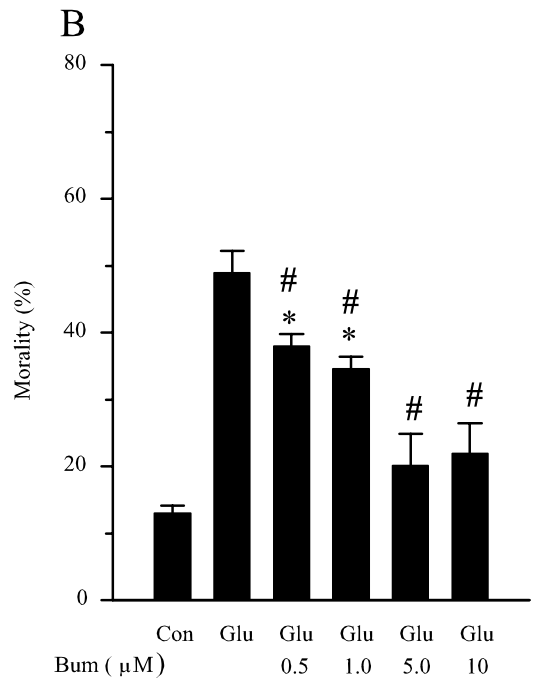

Figure 3. Time-dependent effect of bumetanide on glutamate-mediated neurotoxicity. Cell mortality was assessed in DIV 14-15 neurons by PI and calcein-AM staining after $24 \mathrm{hr}$ of glutamate treatment. Neurons were incubated in EMEM in the presence of $100 \mu \mathrm{m}$ glutamate for $24 \mathrm{hr}$ at $37^{\circ} \mathrm{C} ; 10 \mu \mathrm{m}$ bumetanide was added 30 min before, concurrently, or $10,30,60$, or 120 min after the glutamate treatment. Data are means $\pm \mathrm{SEM} ; n=3-5$. $^{*} p<0.05$ versus control; \# $p<0.05$ versus glutamate by ANOVA (Bonferroni/Dunn). Con, Control; Glu, glutamate; Bum, bumetanide.

Furthermore, activation of NMDA receptors by $100 \mu \mathrm{M}$ NMDA for 15 min induced a significant increase in intracellular ${ }^{36} \mathrm{Cl}$ content (Fig. 7C). This NMDA-mediated rise in intracellular ${ }^{36} \mathrm{Cl}$ content was abolished by NMDA receptor antagonist MK801 $(1 \mu \mathrm{M})$. Inhibition of NKCC1 with $10 \mu \mathrm{M}$ bumetanide also blocked the intracellular ${ }^{36} \mathrm{Cl}$ accumulation. Neither blocking of NKCC1 activity nor NMDA receptors affected the basal levels of intracellular ${ }^{36} \mathrm{Cl}$ content (Fig. 7C). Taken together, the results suggest that $\mathrm{NKCC} 1$ contributes to $\mathrm{Na}^{+}$and $\mathrm{Cl}^{-}$influx during the NMDA-mediated excitotoxicity.

Activation of NKCC1 activity secondary to activation of 


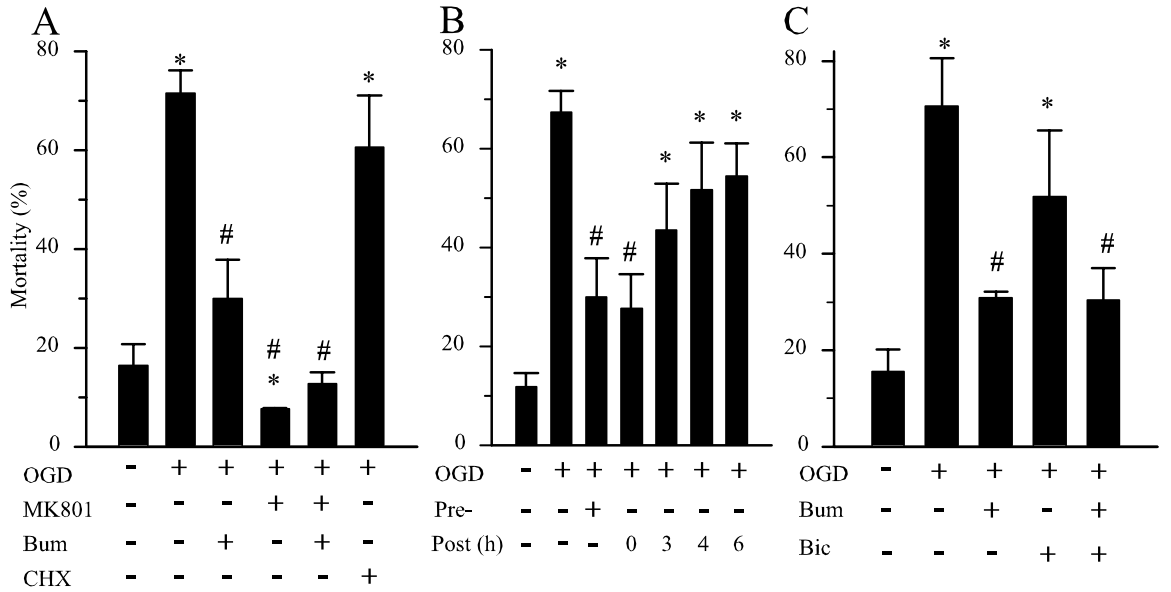

Figure 4. Inhibition of NKCC1 reduces cell mortality after OGD. A, Cell mortality was assessed in DIV $14-15$ neurons by PI and calcein-AM staining after $3 \mathrm{hr} 0 \mathrm{GD}$ and $21 \mathrm{hr}$ reoxygenation. Neurons were preincubated in EMEM containing $10 \mu \mathrm{m}$ bumetanide, $1 \mu \mathrm{m}$ MK-801, bumetanide plus MK801, or $1 \mu \mathrm{m}$ cycloheximide (CHX) for $30 \mathrm{~min}$. The drugs were present during the rest of the incubation period. Data are means $\pm \mathrm{SEM} ; n=3-5 .{ }^{*} p<0.05$ versus control; ${ }^{*} p<0.05$ versus $0 \mathrm{GD}$ by ANOVA (Bonferroni/ Dunn). $B$, Bumetanide ( $10 \mu \mathrm{m}$ ) was added 30 min before, concurrently, or 3,4 , or $6 \mathrm{hr}$ after the $0 \mathrm{GD}$ treatment. Data are means \pm SEM; $n=5-8 .{ }^{*} p<0.05$ versus control; ${ }^{*} p<0.05$ versus $0 G D$ by ANOVA (Bonferroni/Dunn). C, Bicuculline (10 $\mu \mathrm{m}$ ) was added 30 min before the OGD treatment. Data are means $\pm \mathrm{SEM} ; n=3 .{ }^{*} p<0.05$ versus control; ${ }^{\#} p<0.05$ versus 0 GD by ANOVA (Bonferroni/Dunn). Bum, Bumetanide; Bic, bicuculline.
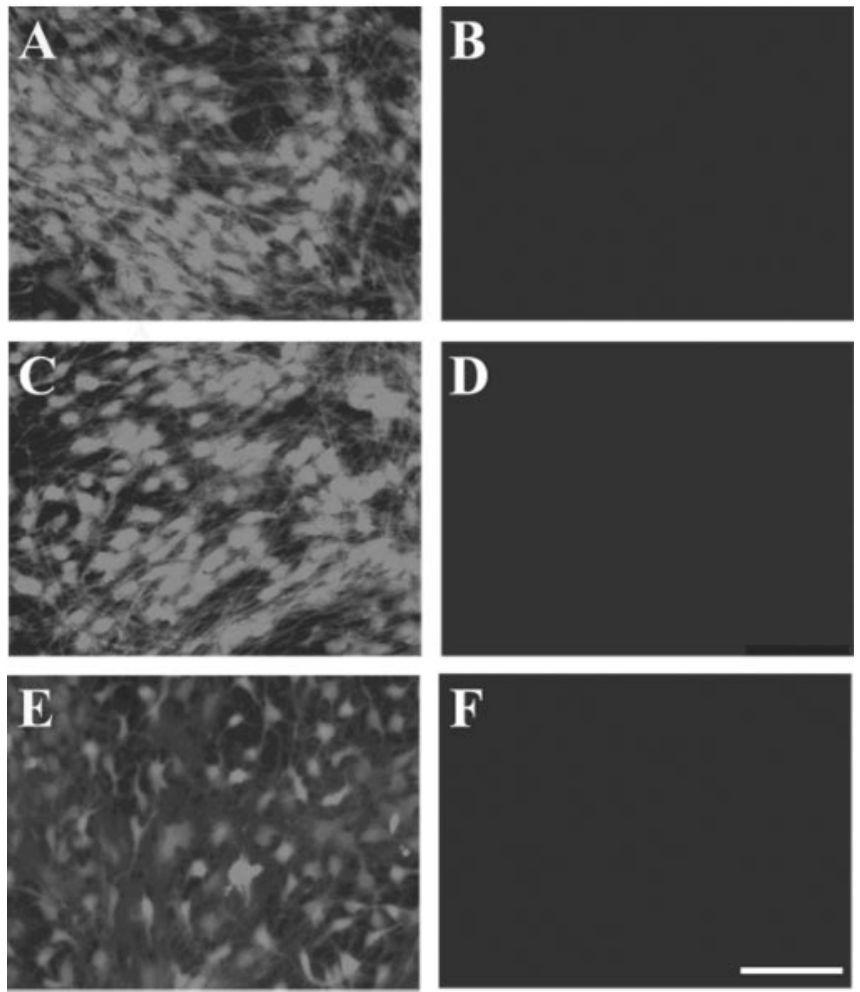

Figure 5. Neither OGD nor glutamate causes cell death in astrocytes. Cell mortality was assessed in DIV 14-15 astrocytes by PI and calcein-AM staining after $24 \mathrm{hr}$ of glutamate (100 $\mu \mathrm{M}$ ) treatment or $6 \mathrm{hr}$ of $0 \mathrm{GD}$ and $18 \mathrm{hr}$ of reoxygenation. $A, C, E$, Calcein-AM. $B, D, F, \mathrm{Pl} . A, B$, Control. C, D, Glutamate. E, F, OGD. Scale bar, $256 \mu \mathrm{m}$.

NMDA receptors will inevitably lead to cell swelling. We examined whether inhibition of NKCC1 activity would attenuate cell swelling as well as ionic influx. As shown in Figure $8 \mathrm{~A}$, concurrent measurement of cell volume with $\left[\mathrm{Na}^{+}\right]_{\mathrm{i}}$ measurements in the same neurons (at room temperature) revealed that $60 \mu \mathrm{M}$ NMDA induced significant swelling that progressed with time.
After 20 min of NMDA exposure, cells had swelled by $\sim 27 \%(\mathrm{CSAr}=1.27 \pm 0.05)$ (Fig. $8 A, B$ ). This NMDA-mediated swelling was sensitive to MK801. In the presence of both NMDA and MK801, swelling was abolished, and the average CSAr values were $1.00 \pm 0.03$ after $20 \mathrm{~min}$ of NMDA exposure (Fig. $8 A, B$ ). Moreover, the NMDA-induced swelling was significantly reduced when NKCC1 was inhibited. Average CSAr values were $1.07 \pm 0.05$ in the presence of both NMDA and $5 \mu \mathrm{M}$ bumetanide (Fig. $8 A, B$ ).

As shown in Figure $8 B$, activation of NMDA receptors at $37^{\circ} \mathrm{Cled}$ to an increase in CSAr values in a similar manner as observed under room temperature conditions. In the presence of NMDA and bumetanide, the rise in CSAr values was significantly attenuated. At $20 \mathrm{~min}$ of NMDA incubation at $37^{\circ} \mathrm{C}$, CSAr values increased by $25 \%$, but only an $8 \%$ increase in CSAr values occurred when NKCC1 was blocked by bumetanide.

We then investigated whether NKCC1 contributed to cell swelling in OGD conditions. After $3 \mathrm{hr}$ of incubation under normoxic control conditions, $\sim 70 \%$ of neurons were swollen by $0-10 \%$ (Fig. $8 C$ ). A small population of control cells increased in cell volume by $10-30 \%$. These changes are likely a result of a temporary change of environmental conditions during imaging (difference in temperature and atmosphere between the incubator and microscope stage, or the absence of serum and growth factors, etc.). No cells increased in volume by $30 \%$ or more under these control conditions. In contrast, $3 \mathrm{hr}$ of OGD led to significant cell swelling. Approximately $80 \%$ of neurons exhibited an increase of CSAr values by $>30 \%$; however, inhibition of NKCC1 activity reduced the number of swollen cells $(>30 \%)$ to $43 \%(p<0.05)$. The results imply that blocking of NKCC1 activity prevents neuronal swelling during OGD and thereby may reduce subsequent cell death. No significant effect of bumetanide on CSAr values was observed under control conditions (data not shown).

\section{Discussion}

\section{Specificity of the pharmacological inhibitor bumetanide} against $\mathrm{NKCC1}$

A role for $\mathrm{Cl}^{-}$ion transporters in neuroexcitotoxicity has been examined previously. Zeevalk et al. (1989) reported that excitotoxicity is attenuated by the $\mathrm{Cl}^{-}$channel blocker disodium $4,4^{\prime}$ diisothiocyanatostilbene-2,2' -disulfonate (DIDS) $(600 \mu \mathrm{M})$, and cellular edema was reduced by the ion transporter antagonist furosemide $(1 \mathrm{~mm})$. These pharmacological approaches are problematic because of the lack of inhibitor specificity at high concentrations. Lerma and Martin del Rio (1992) reported that NMDAinduced currents were reduced by furosemide with an $\mathrm{IC}_{50}$ of $1.23 \pm 0.06 \mathrm{~mm}$, whereas $2 \mathrm{~mm}$ bumetanide inhibited $54 \%$ of the current. DIDS has also been observed to block GABA release (Zeevalk et al., 1989) and kainate-induced currents (Chen et al., 1998). In the present study, we performed a dose-dependent experiment with $0.5-10 \mu \mathrm{M}$ bumetanide. We believe that bumetanide at $0.5-10 \mu \mathrm{M}$ exerts its action solely on NKCC1. This view is based on the following data. First, we conducted dose-responses with bumetanide on NKCC1 activity inhibition in neurons and 


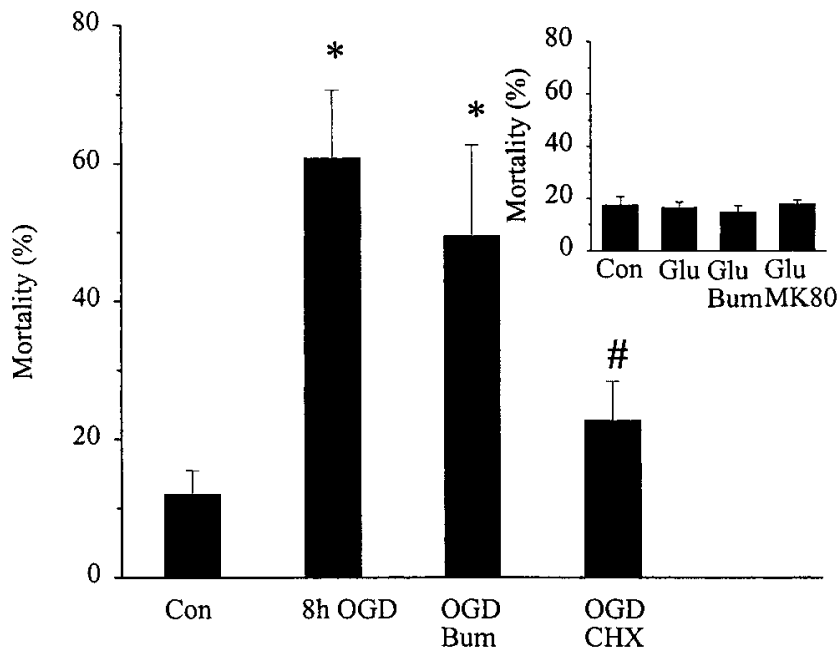

Figure 6. Inhibition of NKCC 1 did not protect DIV 7-8 neurons from cell death after OGD or glutamate exposure. Cell mortality was assessed in DIV 7-8 neurons by PI and calcein-AM staining after $8 \mathrm{hr} 0 \mathrm{GD}$ and $16 \mathrm{hr}$ reoxygenation or $24 \mathrm{hr}$ of glutamate treatment $(100 \mu \mathrm{M})$ (inset). For drug-treated groups, neurons were preincubated in EMEM containing bumetanide $(10 \mu \mathrm{M})$, MK801 $(1 \mu \mathrm{M})$, or cycloheximide $(1 \mu \mathrm{M})$ for $30 \mathrm{~min}$ and remained during the rest of the incubation period. Data are means $\pm \mathrm{SEM} ; n=3-5 .{ }^{*} p<0.05$ versus control; ${ }^{\#} p<0.05$ versus OGD by ANOVA (Bonferroni/Dunn). Con, Control; Bum, bumetanide; CHX, cycloheximide; Glu, glutamate.

found an $\mathrm{IC}_{50}$ of $\sim 0.2 \mu \mathrm{M}$ bumetanide for NKCC1 activity inhibition (data not shown). This value is remarkably similar to $\mathrm{IC}_{50}$ values in other cell types in which bumetanide has proved to be 10-100 times more potent for inhibition of NKCC1 than furosemide in almost all cases (O'Grady et al., 1987; Russell, 2000). Bumetanide at $10 \mu \mathrm{M}$ has no discernible effects on other membrane transport processes such as $\mathrm{Na}^{+} / \mathrm{H}^{+}$or $\mathrm{Cl}^{-} / \mathrm{HCO}_{3}{ }^{-} \mathrm{ex}-$ changers (O'Grady et al., 1987). On the other hand, GABA $\mathrm{A}$ receptors in dorsal root ganglion neurons were inhibited by $10 \mu \mathrm{M}$ bumetanide (Sung et al., 2000). Our results, however, demonstrate that $10 \mu \mathrm{M}$ bumetanide abolished the OGD-mediated cell death, whereas the $\mathrm{GABA}_{\mathrm{A}}$ receptor antagonist bicuculline only attenuated the cell death by $\sim 27 \%$. This further implies that bumetanide acts primarily on NKCC1.

Second, in our recent studies, we have taken both pharmacological inhibition and genetic ablation approaches to block the NKCC1 activity in astrocytes. We reported that blocking of NKCC1 activity in astrocytes with $10 \mu \mathrm{M}$ bumetanide abolishes high-potassium-mediated glial swelling and significantly decreases the release of excitatory amino acids from astrocytes ( $\mathrm{Su}$ et al., 2002a,b). Genetic ablation of NKCC1 also blocks highpotassium astrocyte swelling (Su et al., 2002b). On the basis of the consistent agreement between the pharmacological inhibition and genetic knockout data of the previous studies, as well as a low concentration of bumetanide used in this study, we believe that the bumetanide-mediated effects in the present study represent NKCC1 activity. It is important to confirm these findings using a genetic knock-out model in a future study.

Inhibition of NKCC1 activity in neurons is neuroprotective NKCC1 is important in cell volume regulation and maintenance of intracellular $\mathrm{Na}^{+}, \mathrm{K}^{+}$, and $\mathrm{Cl}^{-}$ion homeostasis under physiological conditions. Overstimulation of NKCC1 may lead to an imbalance of ion homeostasis and contribute to neuronal damage during ischemia (Staub et al., 1994). In neurons with injured axons, $\mathrm{Cl}^{-}$accumulation is attributable to influx of $\mathrm{Cl}^{-}$medi-
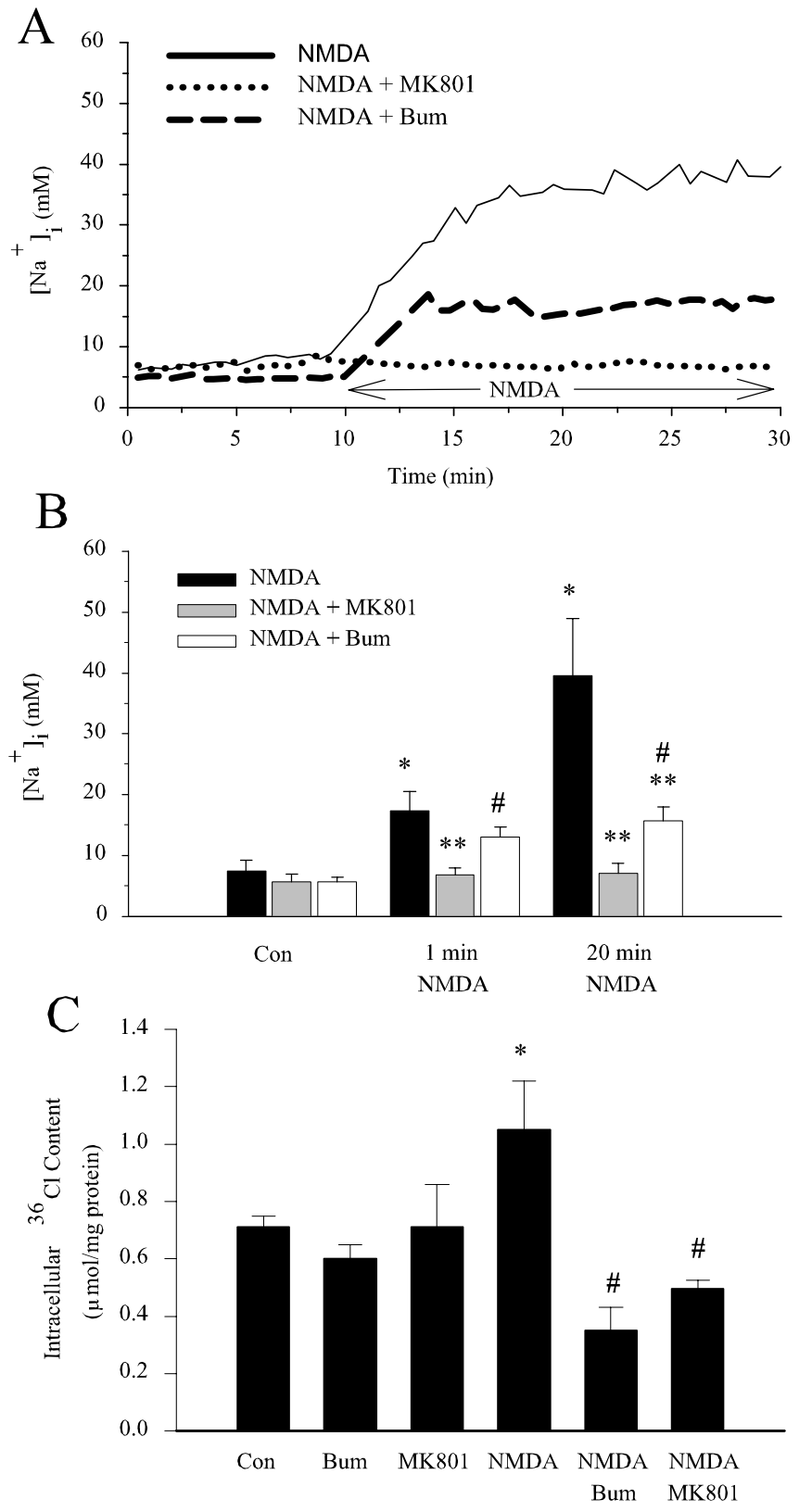

Figure 7. Inhibition of NKCC1 activity by bumetanide reduces intracellular $\mathrm{Na}^{+}$and ${ }^{36} \mathrm{Cl}$ accumulations. $A$, Representative trace of $\left[\mathrm{Na}^{+}\right]_{\mathrm{i}}$ in a single neuron during perfusion of HEPESMEM (10 min) followed by $60 \mu \mathrm{M}$ NMDA (20 min), $1 \mu \mathrm{M}$ MK801 (10 min) followed by $60 \mu \mathrm{M}$ NMDA + $1 \mu \mathrm{M}$ MK801 ( $20 \mathrm{~min})$; or $5 \mu \mathrm{m}$ bumetanide ( $10 \mathrm{~min}$ ) followed by $60 \mu \mathrm{M} \mathrm{NMDA}+5$ $\mu \mathrm{M}$ bumetanide $(20 \mathrm{~min}) . B$, Summary data. Data are means \pm SEM; $n=4-5$ from three different cultures. ${ }^{*} p<0.05$ versus control; ${ }^{* *} p<0.05$ versus $60 \mu \mathrm{M} \mathrm{NMDA} ;{ }^{*} p<0.05$ versus $60 \mu \mathrm{M}$ NMDA $+1 \mu \mathrm{M}$ MK801 (Mann-Whitney rank sum test). C, DIV 14-15 neurons were preincubated in HEPES-MEM for 10 min at $37^{\circ} \mathrm{C}$. Cells were then equilibrated in HEPES-MEM with ${ }^{36} \mathrm{Cl}(0.4 \mu \mathrm{Ci} / \mathrm{ml})$ for $30 \mathrm{~min}$. After a 30 min equilibration with ${ }^{36} \mathrm{Cl}$, neurons were treated with HEPES-MEM containing ${ }^{36} \mathrm{Cl}(0.4 \mu \mathrm{Ci} / \mathrm{ml})$ in either the presence or absence of $10 \mu \mathrm{m}$ bumetanide, $1 \mu \mathrm{m}$ MK801, $100 \mu \mathrm{M}$ NMDA, NMDA plus bumetanide, NMDA plus MK801 for 15 min. Data are means \pm SEM; $n=6-7 .{ }^{*} p<0.05$ versus control; $\#<0.05$ versus NMDAtreated by ANOVA (Bonferroni/Dunn). Bum, Bumetanide; Con, control.

ated by $\mathrm{NKCC} 1$ and a decrease in $\mathrm{Cl}^{-}$extrusion by reduced expression of $\mathrm{K}-\mathrm{Cl}$ contransporter (Nabekura et al., 2002). This leads to a switch of GABA action potential from inhibitory to excitatory and may contribute to excitotoxicity (Nabekura et al., 2002). Recent work from this laboratory (Yan et al., 2001) has shown an upregulation of expression of NKCC1 in brain after 

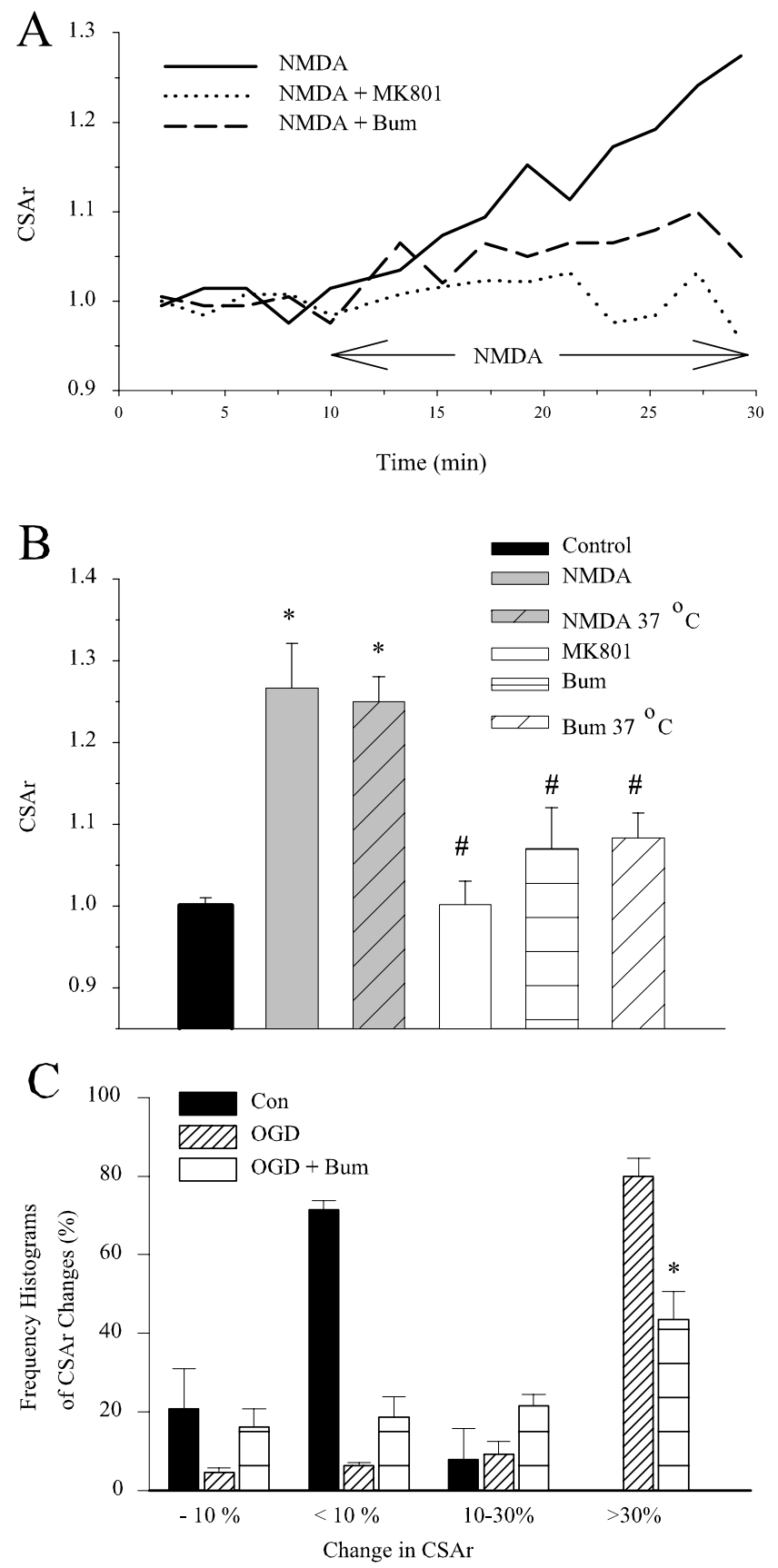

Figure 8. Inhibition of NKCC 1 activity by bumetanide reduces cell swelling. A, At room temperature, mean CSAr value in a single neuron was determined during 10 min of normal HEPESMEM perfusion, followed by 20 min of $60 \mu \mathrm{M}$ NMDA perfusion, or $10 \mathrm{~min}$ of normal HEPESMEM $+5 \mu \mathrm{m}$ bumetanide and 20 min of $60 \mu \mathrm{M}$ NMDA $+5 \mu \mathrm{m}$ bumetanide perfusion, or 10 min HEPES-MEM + $1 \mu \mathrm{m}$ MK801 perfusion, and 20 min of $60 \mu \mathrm{M}$ NMDA $+1 \mu \mathrm{M}$ MK801 perfusion. $B$, The average CSArvalue in single neurons after $20 \mathrm{~min}$ of exposure to HEPES-MEM, $60 \mu \mathrm{M} N M D A, 60 \mu \mathrm{M}$ NMDA $+1 \mu \mathrm{M}$ MK801, or $60 \mu \mathrm{M}$ NMDA $+5 \mu \mathrm{m}$ bumetanide. Data are means \pm SEM; $n=4-5$ from three different cultures. ${ }^{*} p<0.05$ versus control; ${ }^{\#} p<0.05$ versus $60 \mu \mathrm{m}$ NMDA (Mann-Whitney rank sum test). C, Relative change in CSAr value of single neurons from its initial values were determined after $3 \mathrm{hr}$ of incubation in normoxic control, OGD, or OGD plus bumetanide $(10 \mu \mathrm{m})$ conditions. The bars represent neurons with $-10,10$, $10-30$, or $>30 \%$ of control CSAr value. Data are means \pm SEM; $n=3-4 .{ }^{*} p<0.05$ versus OGD by ANOVA (Bonferroni/Dunn). Bum, Bumetanide.

focal cerebral ischemia. Pharmacological inhibition of NKCC1 significantly decreases brain edema and infarct volume in focal cerebral ischemic model (Yan et al., 2001).

To elucidate the cellular mechanisms underlying the role of
NKCC1 in ischemic damage, we examined the effect of inhibition of NKCC1 activity on excitotoxicity mediated by glutamate and OGD. As illustrated in the current study, blockage of NKCC1 activity by bumetanide abolished glutamate-mediated excitotoxicity and significantly decreased OGD-induced neurotoxicity in DIV 14-15 neurons. In contrast, no neuroprotection was observed in DIV 7-8 neurons, which abundantly express NKCC1 (Sun and Murali, 1998) but lack high levels of glutamate receptor (McDonald et al., 1997). Inhibition of protein synthesis by cycloheximide significantly reduced cell death in DIV 7-8 neurons but was ineffective in DIV 14-15 neurons. This is consistent with the early findings that OGD-induced cell death is mediated primarily by apoptosis in immature neurons and is sensitive to cycloheximide (McDonald et al., 1997). This study provides a first line of evidence that $\mathrm{NKCC} 1$ is involved in neuronal death in an in vitro ischemic model. Taken together, the findings from both in vitro and in vivo studies strongly suggest that NKCC1 plays an important role in ischemic necrotic cell damage.

\section{NKCC1 plays a role in acute excitotoxicity}

Numerous reports indicate that acute excitotoxic neurodegeneration after glutamate receptor activation is dependent on $\mathrm{Na}^{+}$ and $\mathrm{Cl}^{-}$entry (Olney, 1971; Rothman, 1985; Choi et al., 1987). Excitotoxic dendritic injury is characterized by the formation of focal swellings along the length of the dendritic arbor (Hasbani et al., 1998). Blockage of $\mathrm{Na}^{+}$and $\mathrm{Cl}^{-}$entry by removal of extracellular $\mathrm{Na}^{+}$and $\mathrm{Cl}^{-}$abolishes excitotoxic dendritic injury, but removal of extracellular $\mathrm{Ca}^{2+}$ has no effect (Hasbani et al., 1998). In rat hippocampal slices, $\mathrm{Na}^{+}$entry blockade by lidocaine and the $\mathrm{Na}^{+}$channel inhibitor tetrodotoxin (TTX) attenuates hypoxia-induced loss of intracellular ATP, inhibition of protein synthesis, and damage of CA1 pyramidal neurons (Raley-Susman et al., 2001). Removal of extracellular $\mathrm{Na}^{+}$or $\mathrm{Cl}^{-}$abolishes NMDA-mediated neurodegeneration in retinal ganglion cells (Chen et al., 1998).

The cellular pathways for the $\mathrm{Na}^{+}$or $\mathrm{Cl}^{-}$entry described above, however, are not fully understood. One mechanism for the excessive $\mathrm{Cl}^{-}$entry is by GABA and glycine receptors. An activation of a $\mathrm{Cl}^{-}$conductance, which is sensitive to $\mathrm{GABA}$ and glycine receptor antagonists, is found in retinal ganglion cells after kainate treatment (Chen et al., 1998). Blockage of GABA and glycine receptors with the antagonists (bicuculline, strychnine) only decreases the NMDA-mediated lactate dehydrogenase release from retina by $50 \%$ (Chen et al., 1998). On the other hand, inhibition of $\mathrm{Na}^{+}$channels by lidocaine and TTX attenuates the hypoxia-mediated $\mathrm{Na}^{+}$accumulation in hippocampal slices by 28 and 20\%, respectively (Raley-Susman et al., 2001). These findings suggest that multiple entry pathways for $\mathrm{Na}^{+}$and $\mathrm{Cl}^{-}$govern the influx of $\mathrm{Na}^{+}$or $\mathrm{Cl}^{-}$during excitotoxicity, in addition to $\mathrm{Na}^{+}$and $\mathrm{Cl}^{-}$channels.

Our study suggests that NKCC1 may act as another mechanism for an overload of intracellular $\mathrm{Na}^{+}$and $\mathrm{Cl}^{-}$during excitotoxicity. This hypothesis is based on the following findings. First, NKCC1 transports $\mathrm{Na}^{+}, \mathrm{Cl}^{-}$, and $\mathrm{K}^{+}$into cells driven by the chemical gradients of three ions. It is well established that the rapidly triggered excitotoxic cell death depends on both $\mathrm{Na}^{+}$and $\mathrm{Cl}^{-}$entry. Thus, NKCC1 is a likely candidate to transport an influx of $\mathrm{Na}^{+}$and $\mathrm{Cl}^{-}$concurrently. Second, NKCC1 has been demonstrated to play an important role in regulation of intracellular $\mathrm{Na}^{+}$and $\mathrm{Cl}^{-}$concentrations and cell volume in many types of cells (Russell, 2000; Su et al., 2002a,b). Activation of NMDA receptors stimulates NKCC1 activity in neurons (Schomberg et al., 2001). In the present study, a rapid increase in neuronal vol- 
ume occurred after OGD or NMDA treatment. Neuronal swelling was significantly attenuated when NKCC1 was blocked. Activation of NMDA receptors triggered a significant increase in $\left[\mathrm{Na}^{+}\right]_{\mathrm{i}}$ and intracellular ${ }^{36} \mathrm{Cl}$ content accumulation. Blocking of NKCC1 activity abolished the $\mathrm{Cl}^{-}$accumulation and attenuated the $\mathrm{Na}^{+}$rise by $52 \%$.

It is generally believed that acute excitotoxic cell damage after glutamate receptor activation is dependent on $\mathrm{Na}^{+}$and $\mathrm{Cl}^{-}$entry, whereas mechanisms leading to delayed cell death are primarily dependent on $\mathrm{Ca}^{2+}$ (Olney, 1971; Rothman, 1985; Choi et al., 1987). We found that blocking of NKCC1 is neuroprotective only when bumetanide was added concurrently with or $30 \mathrm{~min}$ before the glutamate or OGD treatment. The protective effect of bumetanide disappeared if added 10-120 min after the glutamate treatment or 3-6 hr OGD. These findings further suggest that NKCC1 is involved in the initial stage of cell damage during excitotoxicity that depends on extracellular $\mathrm{Na}^{+}$and $\mathrm{Cl}^{-}$.

In summary, pharmacological inhibition of NKCC1 protected neurons from OGD- and glutamate-mediated toxicity. The NKCC1 inhibitor bumetanide reduced cell swelling during excitotoxicity. No protective effect of bumetanide was observed in immature neurons after OGD and glutamate treatment. The results of the study imply that NKCC1 may contribute to ischemic neuronal damage by facilitating excessive $\mathrm{Na}^{+}$and $\mathrm{Cl}^{-}$entry.

\section{References}

Alvarez-Leefmans FJ (2001) Intracellular chloride regulation. In: Cell physiology sourcebook: a molecular approach (Nicholas Sperelakis, ed), pp 301-318. New York: Academic.

Beck J, Lenart B, Kintner D, Sun D (2002) Inhibition of $\mathrm{Na}^{+}-\mathrm{K}^{+}-\mathrm{Cl}^{-} \mathrm{co}-$ transporter attenuates neuronal death induced by glutamate and oxygenglucose deprivation. 9th International Symposium on Pharmacology of Cerebral Ischemia, Marburg, Germany, July.

Chen Q, Olney JW, Lukasiewicz PD, Almli T, Romano C (1998) Ca2+independent excitotoxic neurodegeneration in isolated retina, an intact neural net: a role for $\mathrm{Cl}^{-}$and inhibitory transmitters. Mol Pharmacol 53:564-572.

Choi DW, Maulucci-Gedde M, Kriegstein AR (1987) Glutamate neurotoxicity in cortical cell culture. J Neurosci 7:357-368.

Dent EW, Callaway JL, Szebenyi G, Baas PW, Kalil K (1999) Reorganization and movement of microtubules in axonal growth cones and developing interstitial branches. J Neurosci 19:8894-8908.

Gwag BJ, Koh JY, DeMaro JA, Ying HS, Jacquin M, Choi DW (1997) Slowly triggered excitotoxicity occurs by necrosis in cortical cultures. Neuroscience 77:393-401.

Hasbani MJ, Hyrc KL, Faddis BT, Romano C, Goldberg MP (1998) Distinct roles for sodium, chloride, and calcium in excitotoxic dendritic injury and recovery. Exp Neurol 154:241-258.

Inglefield JR, Schwartz-Bloom RD (1998) Optical imaging of hippocampal neurons with a chloride-sensitive dye: early effects of in vitro ischemia. J Neurochem 70:2500-2509.
Jang IS, Jeong HJ, Akaike N (2001) Contribution of the Na-K-Cl cotransporter on $\mathrm{GABA}(\mathrm{A})$ receptor-mediated presynaptic depolarization in $\mathrm{ex}-$ citatory nerve terminals. J Neurosci 21:5962-5972.

Lerma J, Martin del Rio R (1992) Chloride transport blockers prevent $\mathrm{N}$-methyl-D-aspartate receptor-channel complex activation. Mol Pharmacol 41:217-222.

McDonald JW, Behrens MI, Chung C, Bhattacharyya T, Choi DW (1997) Susceptibility to apoptosis is enhanced in immature cortical neurons. Brain Res 759:228-232.

Misgeld U, Deisz RA, Dodt HU, Lux HD (1986) The role of chloride transport in postsynaptic inhibition of hippocampal neurons. Science 232:1413-1415

Nabekura J, Ueno T, Okabe A, Furuta A, Iwaki T, Shimizu-Okabe C, Fukuda A, Akaike N (2002) Reduction of KCC2 expression and $\mathrm{GABA}_{\mathrm{A}}$ receptormediated excitation after in vivo axonal injury. J Neurosci 22:4412-4417.

Nicklas WJ, Zee valk G, Hyndman A (1987) Interactions between neurons and glia in glutamate/glutamine compartmentation. Biochem Soc Trans 15:208-210.

O'Grady SM, Palfrey HC, Field M (1987) Characteristics and functions of $\mathrm{Na}-\mathrm{K}-\mathrm{Cl}$ cotransport in epithelial tissues. Am J Physiol 253:C177-C192.

Olney JW (1971) Glutamate-induced neuronal necrosis in the infant mouse hypothalamus. An electron microscopic study. J Neuropathol Exp Neurol 30:75-90.

Olney JW, Price MT, Samson L, Labruyere J (1986) The role of specific ions in glutamate neurotoxicity. Neurosci Lett 65:65-71.

Raley-Susman KM, Kass IS, Cottrell JE, Newman RB, Chambers G, Wang J (2001) Sodium influx blockade and hypoxic damage to CA1 pyramidal neurons in rat hippocampal slices. J Neurophysiol 86:2715-2726.

Rothman SM (1985) The neurotoxicity of excitatory amino acids is produced by passive chloride influx. J Neurosci 5:1483-1489.

Russell JM (2000) Sodium-potassium-chloride cotransport. Physiol Rev $80: 211-276$.

Schomberg SL, Su G, Haworth RA, Sun D (2001) Stimulation of Na-K-2Cl cotransporter in neurons by activation of non-NMDA ionotropic receptor and group-I mGluRs. J Neurophysiol 85:2563-2575.

Schomberg SL, Bauer J, Kintner DB, Su G, Flemmer A, Forbush B, Sun D (2003) Cross-talk between the $\mathrm{GABA}_{\mathrm{A}}$ receptor and the Na-K-Cl cotransporter is mediated by intracellular $\mathrm{Cl}^{-}$. J Neurophysiol 87:159-167.

Staub F, Stoffel M, Berger S, Eriskat J, Baethmann A (1994) Treatment of vasogenic brain edema with the novel $\mathrm{Cl}^{-}$transport inhibitor torasemide. J Neurotrauma 11:679-690.

Su G, Kintner DB, Sun D (2002a) Contribution of $\mathrm{Na}^{+}-\mathrm{K}^{+}-\mathrm{Cl}^{-}$cotransporter to high- $\left[\mathrm{K}^{+}\right]_{\mathrm{o}^{-}}$induced swelling and EAA release in astrocytes. Am J Physiol Cell Physiol 282:C1136-C1146.

Su G, Kintner DB, Flagella M, Shull GE, Sun D (2002b) Astrocytes from $\mathrm{Na}^{+}-\mathrm{K}^{+}-\mathrm{Cl}^{-}$cotransporter-null mice exhibit absence of swelling and decrease in EAA release. Am J Physiol Cell Physiol 282:C1147-C1160.

Sun D, Murali SG (1998) Stimulation of $\mathrm{Na}^{+}-\mathrm{K}^{+}-2 \mathrm{Cl}^{-}$cotransporter in neuronal cells by excitatory neurotransmitter glutamate. Am J Physiol 275:C772-C779.

Sung KW, Kirby M, McDonald MP, Lovinger DM, Delpire E (2000) Abnormal GABA $A_{\mathrm{A}}$ receptor-mediated currents in dorsal root ganglion neurons isolated from $\mathrm{Na}-\mathrm{K}-2 \mathrm{Cl}$ cotransporter null mice. J Neurosci 20:7531-7538.

Yan YP, Dempsey RJ, Sun D (2001) $\mathrm{Na}^{+}-\mathrm{K}^{+}-\mathrm{Cl}^{-}$cotransporter in rat focal cerebral ischemia. J Cereb Blood Flow Metab 21:711-721.

Zeevalk GD, Hyndman AG, Nicklas WJ (1989) Excitatory amino acidinduced toxicity in chick retina: amino acid release, histology, and effects of chloride channel blockers. J Neurochem 53:1610-1619. 